\title{
NÉHÁNY GONDOLAT A PPP KONSTRUKCIÓ SZABÁLYOZÁSÁHOZ*
}

\begin{abstract}
Nagy Zoltán ${ }^{1}$
Az irásom Varga Judit a KÖZJAVAK 2015/1. számában megjelent, a PPP témájában született problémafelvetö cikkéhez kapcsolódik ${ }^{2}$, amelyben felteszi a kérdést, hogy egy életképtelen konstrukcióról van szó vagy egy lehetséges alternativáról a közösségi igények kielégitésében. ${ }^{3}$ A kérdés nagyon is aktuálissá vált mind nemzetközi, mind hazai szinten a gazdasági válságot követöen. A szerzö az irásában több problémát is felvet a témával kapcsolatban, amelyekhez néhány gondolatot füzök hozzá.
\end{abstract}

A PPP konstrukció szükségességével kapcsolatban felveti a szerző a fenntartható közfeladat-ellátás kérdését, nagyon helyesen rámutatva, hogy a közbevételek véges volta korlátozza a közfeladat-ellátás bővítését illetve a minöségi színvonalának az emelését. Ezzel a problémával a hazai államháztartási gazdálkodás is szembe találja magát, amellyel összefüggésben az Alaptörvényben találunk rendelkezéseket. Az Alaptörvény a fenntartható államháztartási gazdálkodás alapkövének az államadósságszabályt tekinti, vagyis olyan költségvetési gazdálkodást kell folytatni, amelynek következtében nem nő az államadósság mértéke és hosszabb távon elérhető az alaptörvényi optimális államadósság, a GDP 50\%-t kitevő államadósság. Ezt azért tartja fontosnak és a fenntarthatóság alapvető tényezöjének a jogalkotó, mivel a jelenleg felhasznált források terheit a jövő nemzedékének kell viselni, a keletkező államadósságot és kamatait megfizetni. A szabály az egyes közfeladat-ellátásoknál úgy vetődik fel, hogy van-e pénzügyi fedezet a közfeladat ellátására. Ha nincs akkor nem végezhető a közfeladat, vagy nem költségvetési forrásból (természetesen a kötelező közfeladatok ellátása más elbírálás alá esik). A PPP konstrukció ilyen szempontból egy jó lehetőség lenne arra, hogy magánforrások bevonására kerüljön sor a közfeladatellátásban.

A másik probléma, hogy mit célszerü ilyen konstrukcióban megvalósítani, hiszen PPP legtöbb esetben olyan előrehozott beruházások megvalósítására szolgál, amelyek a közszolgáltatás minőségét vagy mennyiségi lehetőségeit növelik. Álláspontom szerint olyan beruházások megvalósítására kerülhet sor, amely elősegíti a gazdasági növekedést és hosszabb távon is fenntartható, gazdaságosan üzemeltethető. Ellenkező esetben a költségvetési politikának kell mérlegelnie az adott közfeladat-ellátást és döntetni arról, hogy esetlegesen a nem gazdaságos, de fontos társadalmi célokat szolgáló beruházást is megvalósítja és fenntartja. Ez utóbbi esetben viszont nem célszerü a magántőke bevonása.

\footnotetext{
${ }^{*}$ DOI 10.21867/KjK/2017.2.2.

${ }^{1}$ Dr. habil. Nagy Zoltán, egyetemi docens, ME ÁJK

${ }^{2}$ Varga Judit: Eletképtelen jogalkotási vadhajtás vagy a közösségi igények kielégitésének müködőképes alternativája? KÖZJAVAK I. évfolyam, 2015/1. szám, 17-20.

${ }^{3}$ Varga Judit egyébként a téma szakértője, aki a PPP szabályozást tudományos disszertációban is feldolgozta. Varga Judit: A partnerség (PPP) szerepének változása a közpénzügyek jogában. Disszertáció, Debrecen, 2016.
} 
A gazdasági növekedést elősegítő beruházások körébe sorolhatóak a humánerőforrás megőrzését és fejlesztését szolgáló beruházások illetve a gazdasági fejlődést elősegítő infrastrukturális beruházások. Az elöbbi körbe tartoznak többek között az egészségügyi, egészség megőrzési szolgáltatások, népesség megőrzését elősegítő és az oktatást fejlesztő szolgáltatások. A gazdasági növekedés egyik legfontosabb tényezője a humánerőforrás, ezért az ebbe beleinvesztált köz- és magánforrások egyaránt megtérülnek a nemzetgazdaság szintjén. Ez tehát egy olyan megtérülö beruházás, amely alkalmas a PPP konstrukciók megvalósulására. A hazai példán azonban látszik, hogy a felsőoktatás körében megvalósult beruházások ${ }^{4}$ lettek a PPP beruházások ,állatorvosi lovai”, szinte minden probléma felszínre került a konstrukcióval kapcsolatban. ${ }^{5}$

Önmagában véve nem a konstrukció elvetendő voltát erősítette meg szerintem a felsőoktatási PPP-k megvalósulása, hanem arra mutatott rá, hogy ezek a konstrukciók meröben eltérnek a költségvetési szféra szabályrendszerétöl.

Ilyen probléma a konstrukciók magas árszínvonala, amely vezetett többek között a konstrukció központi költségvetési kivásárlásához. A költségek magasabb szintje természetes a magánfinanszírozásnál, hiszen itt nyereséget kíván elérni a befektető, amellett, hogy sok esetben a finanszírozási költségek is terhelik a beruházást. Természetszerü, hogy olcsóbb az egyösszegü költségvetési pénz felhasználása közösségi beruházásoknál, de ha nincs ilyen forrás és szükség van a beruházásra, akkor vállalni kell a többletköltségeket is a költségvetésnek.

A másik probléma a közjogi és polgári jogi szabályozás, illetve a közjogi és magánjogi finanszírozás konfliktusa a konstrukció kapcsán. A közjogi keretek és költségvetési finanszírozás alatt álló szervezetek szerződnek magánjogi szervezetekkel. A szerződés is sajátos, tartalmaz közjogi és magánjogi elemeket egyaránt. Az egyes költségvetési szervek nem minden esetben felkészültek szakmailag a sajátos magánjogi keretek értelmezésére és abból származó hosszú távú kötelezettségek megítélésére. Sok esetben vezérli a költségvetési szerveket az a szemlélet, hogy majd a központi költségvetés megoldja a hosszabb távon felmerülö problémákat, a fontos a jelenlegi szolgáltatások magas színvonalú biztosítása.

De a konstrukció problémákat hordoz a magánbefektetők számára is. Ez alatt értendő a kiszámíthatatlan gazdaságpolitika és szabályozási környezet, amely hosszútávon történő tervezést nem segíti elő illetve kockázatossá teszi a konstrukciót, amely felárat eredményez a finanszírozás kapcsán és olyan mértékben megdrágíthatja a PPP-t, hogy már nem biztos, hogy megtérül meg a beruházás.

Összegzésképpen megállapítható, hogy változásokra van szükség a konstrukció kapcsán, szükséges lenne egyértelmü jogi szabályozás kialakítására, mind a magánjog, mind pedig a közjogi szabályozás területén egyaránt, amely megnyugtató támpontokat adna mind a magánbefektetők, mind pedig a költségvetési szervek számára.

4 http://index.hu/gazdasag/ado_es_koltsegvetes/2016/12/19/ppp-n_sporolnanak_a_felsooktatasban/ (letöltés dátuma: 2017. augusztus 15.)

5 .Közpénzek közérthetően: PPP konstrukció a felsőoktatásban: www.aszhirportal.hu/hirek/a_ppp_konstrukcioban_epult_kollegiumok_hasznosulasa http://index.hu/gazdasag/ado_es_koltsegvetes/2016/12/19/ppp-n_sporolnanak_a_felsooktatasban/ (letöltés dátuma: 2017. augusztus 15.) 